\title{
Use of an area-based survey technique to detect vegetation changes in Sour Bushveld
}

\author{
M.D. Panagos AND B.K. Reilly
}

Panagos, M.D. and B.K. Reilly. 2006. Use of an area-based survey technique to detect vegetation changes in Sour Bushveld. Koedoe 49(1): 69-78. Pretoria. ISSN 0075-6458.

\begin{abstract}
Most strategies for monitoring vegetation change on reserves and game ranches are based on point methods. Area-based methods form the basis of initial floristic classifications from which vegetation maps are constructed. The question arises whether or not these area-based methods can be used for monitoring or not. This paper compares two area-based data sets from the same sites with an intervening period of five years. Data were collected on a Sour Bushveld game farm, in the Limpopo Province of South Africa. The structure of the woody vegetation, particularly in two communities reflected a plant successional progression over time. All six re-surveyed sites reflected an increase in plant species richness and this increase was most substantial in one community where the total number of plant species increased from 17 in 1996 to 34 in 2001 at one sampling site and from 26 in 1996 to 45 in 2001 at the other. This study has shown that change in species composition can be detected using area-based sampling techniques but that absolute measures, such as density, should be employed rather than estimates, especially with regard to plant cover.
\end{abstract}

Keywords: area-based vegetation sampling, species composition, structure, canopy cover

M.D. Panagos $\triangle$ and B.K. Reilly, Department of Nature Conservation, Tshwane University of Technology, Private Bag X680, Pretoria, 0001 Republic of South Africa.

\section{Introduction}

Monitoring has been defined as "the maintenance of regular surveillance to test the null hypothesis of no change in predefined properties of a system which is vulnerable to impacts, the nature and timing of which are not necessarily known" (Mentis 1984). Ferrar (1983) states that monitoring and evaluation of vegetation is the key to natural resource management and vegetation monitoring involves three fundamental steps: a) quantification of the vegetation characteristics; b) assessment of any change to these characteristics over time; and c) projection of trends in these characteristics in the future. Despite vegetation monitoring enjoying considerable attention in the 1970s and 1980s, this vital veld management action has unfortunately not been sustained due to inappropriate and time consuming techniques being used (Short et al. 2003).
Point-based techniques originally proposed by Levy \& Madden (1933) and later Dyksterhuis (1949) have been adopted and variously modified in South Africa, starting with the development of the wheel-point technique (Tidmarsh \& Havenga 1955), the nearest plant method (Foran et al. 1978), the benchmark method (Tainton et al. 1980) and the foot-point method (Mentis 1981). More recently, a so-called key species technique was developed (Trollope 1990) and implemented in the Kruger National Park. They have been shown to be efficient in terms of time when compared to area-based sampling (Panagos \& Zacharias 1995) and lend themselves readily to statistical analyses. However, since these techniques make use of only 100 or 200 points for data collection, their ability to show change with high precision has been questioned in terms of basal cover (Mentis et al. 1980), less frequently encountered plants (Everson et al. 1990; O'Connor 
\& Roux 1995; Panagos 1995; Short et al. 2003), and statistical power (Reilly \& Panagos 2002). Also, all of these techniques are used primarily for measuring the condition of the grass sward and seldom include nongraminoid plants (when these plants are included they are lumped into two broad categories termed 'forbs' and 'woodies'). More recently, techniques such as BECVOL (Smit 1989) and the revised procedure for conducting veld condition assessments (VCAs) in the Kruger National Park (Zambatis 2002) have been included with herbaceous layer techniques to include some form of woody stratum evaluation. Furthermore, problems arise when attempts are made to show change over time using relative measures of single species. The increase or decrease in a particular species' relative frequency is masked as an artifact of changes in other species. This situation is improved by lumping species into indicator guilds but the situation is not ideal in terms of showing change over time.

Area-based field sampling techniques, on the other hand, have historically been employed in the mapping and classification of vegetation and this is well documented. These survey techniques have involved recording all rooted plants present within a square or rectangular unit of varying sizes (termed a quadrat) and then assigning some estimation of percentage canopy cover to each species recorded in the quadrat using a cover class value. Density, biomass, and frequency were not recorded in these units when the end product was a vegetation classification and map. What is not well documented is the use of this technique for the detection of vegetation change although the authors are aware of a number of ecologists who advocate and use this technique to monitor vegetation as part of a managerial action on game reserves and game ranches. The lack of the largescale use of an area-based sampling technique to detect vegetation change is because it is time consuming since all species (woody plants, forbs and grasses) within a demarcated sampling unit have to be identified, recorded and quantified. Thus, fewer sites are completed for a study than would be the case using a point-based technique. Also, historically, many of these sampling sites were chosen subjectively, not geo-referenced and the measure of cover-abundance used to quantify the species present in the sampling plot was, at best, a subjective estimate. Areabased sampling has been historically difficult to repeat and does not readily lend itself to statistical analyses. Data collected following the Braun-Blanquet approach, has been shown to be of use in assessing veld condition (Westfall et al. 1983; Eckhardt et al. 1993) and, more recently, a concerted effort has been made to make area-based sampling techniques more objective and thus of possible use in vegetation monitoring (Westfall et al. 1996, Westfall et al. 1997, Panagos et al. 1998).

This paper explores the ability (or lack thereof) of an area-based vegetation survey technique to detect change in the structure, composition and cover of the vegetation at the same sites with a five-year intervening period.

\section{Study area}

The study area comprises the farm Weltevreden $135 \mathrm{KR}$ situated in the Limpopo Province, approximately $30 \mathrm{~km}$ east of Vaalwater at $24^{\circ} 18^{\prime} \mathrm{S}-24^{\circ} 23^{\prime} \mathrm{S}, 28^{\circ} 08^{\prime} \mathrm{E}-28^{\circ} 13^{\prime} \mathrm{E}$, and is approximately 700 ha in extent. The vegetation of the farm forms part of the Savanna Biome (Rutherford \& Westfall 1986) and occurs in Veld Type 20 or Sour Bushveld (Acocks 1988). The main physiographic features of the study area are: the southern edge of the Sandriviersberge (2041 $\mathrm{m}$ a.s.1.) in the south; the Groot Wolwefontein River on the eastern boundary draining the farm in a northerly direction; and an undulating plateau (1080-1190 m a.s.1.) in the west and north. The geology of the farm forms part of the Kransberg sub group of the Waterberg Group (2428 Nylstroom 1:250 000 geological map). No detailed soil survey exists for the study area. However, the farm is included on the 1:250 000 Nylstroom (2428) Land Type map 
and consists of two land types namely the $\mathrm{Bb}$ and $\mathrm{Fa}$ land types described by the Land Type Survey Staff (1988). The Bb land type consists mainly of Hutton and Clovelly soil forms (deep sandy soils), while the Fa land type consists mainly of Mispah and Glenrosa soil forms (shallow soils) (MacVicar et al. 1977). Climatic data for Weltevreden, obtained from the AGROMET (1996) database, based on data recorded at the Vaalwater weather station for 18 years, show that the area has a mean annual rainfall of 606 $\mathrm{mm}$ and a mean monthly maximum temperature of $29.7^{\circ} \mathrm{C}$ and a mean monthly minimum temperature of $3.6^{\circ} \mathrm{C}$.

\section{Methods}

The quantification of the vegetation characteristics commenced in 1996 when a base-line survey of the farm Weltevreden $135 \mathrm{KR}$ was completed. Three plant communities were identified using floristic data recorded in 12 quadrats $(10 \mathrm{~m} \times 20 \mathrm{~m})$ that were placed in stratified units delineated using aerial photographs at a scale of 1:12 000 .

In February 2001, a monitoring programme, as defined above, was implemented with the re-survey of six of the original twelve sampling sites. The same fieldworker (1st author) solely collected field data during both time periods. These six sites were randomly chosen (two in each plant community) and located using previously recorded GPS readings. Site orientation was replicated with the use of a permanent marker and a compass bearing of the long side of the quadrat. Floristic parameters recorded during the baseline survey were recorded again at each of the six sample sites, viz., the presence or absence of plant species within the quadrats, the assignment of growth forms to each species recorded (tree, shrub, dwarf-shrub, grass \& forb) following Westfall et al. (1996) and an estimate of canopy cover for each species recorded, in variably sized transects, based on the average crown to gap ratio (Westfall \& Panagos 1988). Plant taxa recorded in a sample site were identified using existing knowledge and field guides such as Van Oudtshoorn (1992), Van Wyk \& Malan (1988) and Coates-Palgrave (1988). Plant species names or nomenclature is that used by the National Herbarium, Pretoria as described in Germishuizen \& Meyer (2003). Where a positive field identification was not possible, plants were assigned a field 'nickname', collected and later identified by a credible plant taxonomist. Vegetation structure was classified according to Edwards (1983) and is based on the cover and the height of the plants present in each community.

Data were analysed per community for change over time by comparing:

- net gain/loss of plant species in each quadrat within each growth form to detect an increase/decrease in plant species richness;

- change in canopy cover within each growth form in each qaudrat to detect changes in vegetation structure; and

- ratios of herbaceous plants (grasses and forbs) to woody growth forms in each quadrat.

All three of these parameters can be used to determine the condition of the vegetation.

In terms of statistical analyses for percentage canopy cover, a chi-square statistic was computed for each site in each community with the 1996 as the expected value and 2001 as the observed value (H0: no change over time). Similarly, chi-square statistics were computed for all the species in all growth forms for the six re-surveyed sites from 1996 to 2001. Although chi-square is idealy suited to use with frequencies it is applied in this case as a test of association or homogeneity. All analyses were done using STATISTICA (StaSoft Inc. 1995).

\section{Results}

The results of the follow-up survey are presented for each of the three plant communities identified on the farm Weltevreden.

\section{Lannea discolor - Aristida meridionalis Low Closed Woodland (Community 1)}

There was a significant change in this community in terms of percentage canopy cover from 1996 to $2001\left(\chi^{2}=15.63 ; d f=4 ; p=\right.$ 0.0035 and $\chi^{2}=89.16 ; d f=4 ; p=0.00$ for sites 1 and 3 respectively) (Table 1 ). The number of woody species in Community 1 remained more or less constant over the fiveyear period (Table 2). However, the woody plant structure in terms of growth forms and canopy cover had changed considerably in Site 3 from an open woodland with more shrubs and dwarf shrubs in 1996, to a closed woodland having fewer shrubs and dwarf shrubs and more trees in 2001 (Table 1). Site 1 shows a similar trend with an increase in the tree growth form and canopy cover. These observations are borne out by the test 
Table 1

Percentage canopy cover recorded for Community 1 on the farm Weltevreden in 1996 and 2001

\begin{tabular}{lrrlrr}
\hline Sample site 1 & 1996 & 2001 & Sample site 3 & 1996 & 2001 \\
\hline Trees & 6.5 & 10.1 & Trees & 12.3 & 36.4 \\
Shrubs & 6.5 & 6.8 & Shrubs & 20.5 & 0.5 \\
Dwarf shrubs & 8.8 & 1.0 & Dwarf shrubs & 2.9 & 0.2 \\
Grasses & 28.6 & 15.4 & Grasses & 7.3 & 16.6 \\
Forbs & 0.4 & 0.9 & Forbs & 0.6 & 2.8 \\
\hline Total & 50.2 & 34.2 & Total & 43.5 & 56.5 \\
\hline
\end{tabular}

statistics of each growth form in the significance test. The number of grass species remained relatively constant in Site 1 but increased overall in Site 3 by four grasses (one annual and three perennials) (Table 2). Grass cover declined by $13 \%$ in Site 1 but increased by $7 \%$ in Site 3 (Table 1). Forb species increased considerably in Site 1 from seven species in 1996 to 16 species in 2001 but remained constant in Site 3 (Table 2). The percentage cover for forbs did not change much over the five-year period in either of the sample sites (Table 1). This growth form (forbs) was mainly responsible for an increase in species richness in Site 1 from 34 species in 1996 to 42 species in 2001. The total number of species in Site 3 increased from 34 to 37 . The ratio of forbs to other

Table 2

Change in species numbers per growth form in Community 1 on the farm Weltevreden between 1996 and 2001

\begin{tabular}{|c|c|c|c|c|c|}
\hline \multicolumn{3}{|l|}{ Sample site 1} & \multicolumn{3}{|l|}{ Sample site 3} \\
\hline Number of woody plant species & s 1996 & 2001 & Number of woody plant species & 1996 & 2001 \\
\hline Trees & 1 & 2 & Trees & 3 & 11 \\
\hline Shrubs & 2 & 5 & Shrubs & 3 & 2 \\
\hline Dwarf shrubs & 13 & 7 & Dwarf shrubs & 10 & 2 \\
\hline $\begin{array}{l}\text { Total number of woody } \\
\text { species \& species turnover }\end{array}$ & $\begin{array}{c}16 \\
3 \mathrm{DS} \\
\text { missing }\end{array}$ & $\begin{array}{l}14 \\
1 \mathrm{DS} \\
\text { new }\end{array}$ & $\begin{array}{l}\text { Total number of woody } \\
\text { species \& species turnover }\end{array}$ & $\begin{array}{c}16 \\
5 \mathrm{DS} \\
\text { missing }\end{array}$ & $\begin{array}{c}15 \\
3 \mathrm{~T}, 1 \mathrm{~S}, \\
1 \mathrm{DS} \text { new }\end{array}$ \\
\hline Number of grass species & 1996 & 2001 & Number of grass species & 1996 & 2001 \\
\hline Annuals & 1 & 1 & Annuals & 1 & 2 \\
\hline Perennials & 10 & 11 & Perennials & 7 & 10 \\
\hline $\begin{array}{l}\text { Total number of grass } \\
\text { species \& species turnover }\end{array}$ & $\begin{array}{c}11 \\
1 \text { missing }\end{array}$ & $\begin{array}{l}12 \\
2 \text { new }\end{array}$ & $\begin{array}{l}\text { Total number of grass } \\
\text { species \& species turnover }\end{array}$ & $\stackrel{8}{0 \text { missing }}$ & $\begin{array}{c}12 \\
4 \text { new }\end{array}$ \\
\hline $\begin{array}{l}\text { Total number of forb } \\
\text { species \& species turnover }\end{array}$ & $\begin{array}{c}1996 \\
7 \\
1 \text { missing } \\
\end{array}$ & $\begin{array}{c}2001 \\
16 \\
10 \text { new }\end{array}$ & $\begin{array}{l}\text { Total number of forb species } \\
\& \text { species turnover }\end{array}$ & $\begin{array}{c}1996 \\
10 \\
5 \text { missing }\end{array}$ & $\begin{array}{c}2001 \\
10 \\
5 \text { new }\end{array}$ \\
\hline $\begin{array}{l}\text { Total species for all } \\
\text { growth forms }\end{array}$ & 34 & 42 & $\begin{array}{l}\text { Total species for all } \\
\text { growth forms }\end{array}$ & 34 & 37 \\
\hline
\end{tabular}


Table 3

Percentage canopy cover in Community 2 on the farm Weltevreden in 1996 and 2001

\begin{tabular}{lcclcc}
\hline Sample site 5 & 1996 & 2001 & Sample site 9 & 1996 & 2001 \\
\hline Trees & 1.0 & 12.7 & Trees & 27.9 & 33.8 \\
Shrubs & 11.0 & 0.0 & Shrubs & 0.0 & 0.1 \\
Dwarf shrubs & 0.5 & 1.4 & Dwarf shrubs & 0.4 & 1.9 \\
Grasses & 9.0 & 13.7 & Grasses & 7.6 & 12.3 \\
Forbs & 0.1 & 0.2 & Forbs & 0.4 & 0.8 \\
\hline Total & 21.6 & 28.0 & Total & 36.3 & 48.9 \\
\hline
\end{tabular}

species for these two sites was 38\% (16/42) in Site 1 and $27 \%(10 / 37)$ in Site 3. The proportion of grasses to other species was $29 \%$ and $32 \%$ in Sites 1 and 3 respectively. There was a significant change in this community in terms of number of plant species from 1996 to $2001\left(\chi^{2}=19.94 ; d f=\right.$ $5 ; p=0.0013$ and $\chi^{2}=30.35 ; d f=5 ; p=0.00$ for sites 1 and 3 respectively).
2. The Rhus gracillima - Dichapetalum cymosusm Low Closed Woodland (Community 2)

The woody species richness in Community 2 remained relatively constant with an overall species decrease in Site 5 and an increase in species in Site 9 (Table 4). Change from 1996 to 2001 was significant in terms of per-

Table 4

Change in species numbers per growth form in Community 2 on the farm Weltevreden between 1996 and 2001

\begin{tabular}{|c|c|c|c|c|c|}
\hline \multicolumn{3}{|c|}{ Sample site 5} & \multicolumn{3}{|l|}{ Sample site 9} \\
\hline $\begin{array}{l}\text { Number of woody } \\
\text { plant species }\end{array}$ & 1996 & 2001 & $\begin{array}{l}\text { Number of woody } \\
\text { plant species }\end{array}$ & 1996 & 2001 \\
\hline Trees & 3 & 4 & Trees & 3 & 5 \\
\hline Shrubs & 3 & 0 & Shrubs & 1 & 2 \\
\hline Dwarf shrubs & 6 & 6 & Dwarf shrubs & 11 & 13 \\
\hline $\begin{array}{l}\text { Total number of woody } \\
\text { species \& species turnover }\end{array}$ & $\begin{array}{c}12 \\
1 \mathrm{~T}, 1 \mathrm{~S}, \\
2 \mathrm{DS} \text { missing }\end{array}$ & $\begin{array}{c}10 \\
2 \mathrm{DS} \\
\text { new }\end{array}$ & $\begin{array}{l}\text { Total number of woody } \\
\text { species \& species turnover }\end{array}$ & $\begin{array}{c}15 \\
2 \mathrm{DS} \\
\text { missing }\end{array}$ & $\begin{array}{c}20 \\
1 \mathrm{~T}, 1 \mathrm{~S} \\
5 \mathrm{DS} \text { new }\end{array}$ \\
\hline $\begin{array}{l}\text { Number of grass species } \\
\text { Annuals } \\
\text { Perennials }\end{array}$ & $\begin{array}{c}1996 \\
2 \\
7\end{array}$ & $\begin{array}{c}2001 \\
3 \\
10\end{array}$ & $\begin{array}{l}\text { Number of grass species } \\
\text { Annuals } \\
\text { Perennials }\end{array}$ & $\begin{array}{c}1996 \\
1 \\
7\end{array}$ & $\begin{array}{c}2001 \\
4 \\
9\end{array}$ \\
\hline $\begin{array}{l}\text { Total number of grass } \\
\text { species \& species turnover }\end{array}$ & $\begin{array}{c}9 \\
2 \text { missing }\end{array}$ & $\begin{array}{c}13 \\
6 \text { new }\end{array}$ & $\begin{array}{l}\text { Total number of grass } \\
\text { species \& species turnover }\end{array}$ & $\begin{array}{c}8 \\
2 \text { missing }\end{array}$ & $\begin{array}{l}13 \\
7 \text { new }\end{array}$ \\
\hline $\begin{array}{l}\text { Total number of forb } \\
\text { species \& species turnover }\end{array}$ & $\begin{array}{c}1996 \\
6 \\
5 \text { missing }\end{array}$ & $\begin{array}{c}2001 \\
5 \\
4 \text { new }\end{array}$ & $\begin{array}{l}\text { Total number of forb } \\
\text { species \& species turnover }\end{array}$ & $\begin{array}{c}1996 \\
3 \\
1 \text { missing }\end{array}$ & $\begin{array}{c}2001 \\
12 \\
10 \text { new }\end{array}$ \\
\hline $\begin{array}{l}\text { Total species for all } \\
\text { growth forms }\end{array}$ & 27 & 28 & $\begin{array}{l}\text { Total species for } \\
\text { all growth forms }\end{array}$ & 17 & 32 \\
\hline
\end{tabular}


centage canopy cover $\left(\chi^{2}=152.06 ; d f=4\right.$; $p=0.00$ and $\chi^{2}=10.18 ; d f=4 ; p=0.038$ for sites 5 and 9 respectively) (Table 3 ). Scrutiny of the statistics shows that the change in the structure is disproportionate in the shrub layer; in essence the significant change can be almost entirely attributed to changes in this layer. Tree cover increased in both sites, shrub cover declined in Site 5 and remained constant in Site 9. Dwarf shrub cover increased in both sites (Table 3). The number of grass species showed an overall increase in richness with four new grasses in Site 5 (one annual and three perennials) and five new grasses in Site 9 (three annuals and two perennials) (Table 4). Grass cover showed an overall improvement in both sites (Table 3). Forb cover increased slightly in both sites (Table 3) and species richness in this growth form decreased in Site 5 but increased in Site 9 (Table 4). The increase in grass and forb species in Site 9 resulted in the total species richness for this site increasing from 17 species in 1996 to 32 in 2001 (Table 4). The ratio of forbs to other species in Site 5 was $18 \%(5 / 28)$ and in Site 9 was $38 \%(12 / 32)$. The proportion of grasses to other species was $46 \%$ and $41 \%$ in Sites 5 and 9 respectively. There was an insignificant change in this community in terms of number of species from 1996 to 2001 in site $5\left(\chi^{2}=5.29 ; d f=5\right.$; $p=0.38)$ and a significant change in Site 9 $\left(\chi^{2}=39.27 ; d f=5 ; p=0.00\right)$.

\section{Lannea edulis - Eragrostis pallens Low Closed Woodland (Community 3)}

Species composition changed significantly in this community from 1996 to 2001 $\left(\chi^{2}=153.3 ; d f=4 ; p=0.00\right.$; and $\chi^{2}=83.56$; $d f=4 ; p=0.00$ ) (Table 6). The canopy cover measured for all five growth forms in this community did not change significantly during the five-year period (Table 5). Tree cover decreased slightly in both sites, shrub cover remained the same, dwarf shrub cover increased slightly and grass and forb cover remained relatively constant (Table 5). However, the change in species richness was considerable in both re-surveyed sites (Table 6). In Site 11, species richness increased from
13 species in 1996 to 34 species in 2001, mainly in the grass and forb growth forms. Grasses increased from three to 13 species and forbs increased from one to nine species. Site 12 showed increases in all growth form categories: woody species increased from seven to 16 mainly due to eight new dwarf shrubs; grasses increased from six to nine species and forbs increased from four to seven species. The forb component in Site 11 comprised $26 \%(9 / 34)$ and in Site 12, $16 \%$ (7/45) of the species present were forbs. The proportion of grasses to other plant species was $38 \%$ and $20 \%$ in Sites $11 \& 12$ respectively. Once again the there was a significant change in this community in terms of number of species from 1996 to $2001\left(\chi^{2}=71.13\right.$; $d f=5 ; p=0.00$ and $\chi^{2}=24.63 ; d f=5 ; p=$ 0.00 for sites 11 and 12 respectively).

\section{Discussion}

The structure of the woody vegetation, particularly in Communities $1 \& 2$ reflected a plant successional progression. In 1996, the structure of the vegetation in these two communities was dominated by plants in the shrub and dwarf shrub strata. These two communities had become tall closed woodlands dominated by more plants in the tree stratum i.e. the shrubs and dwarf shrubs had grown into trees. The tree cover in these two communities increased appreciably, in some cases more than double its original amount and the shrub and dwarf shrub strata decreased or remained constant, i.e. although these two growth forms were present in these two communities, their cover had been reduced. The tree cover in Community 3 decreased slightly, while the cover for shrubs and dwarf shrubs increased in this community. From a management perspective, the increase in tree cover and decrease in shrub and dwarf shrub cover tends to 'open up' the woody vegetation. The maintenance of plants in the shrub or dwarf shrub strata often leads to an increase in density and ultimately bush thickening. Bush thickening was not evident at the time of re-surveying, save for a small area in Community 2 where 
Table 5

Percentage canopy cover in Community 3 on the farm Weltevreden in 1996 and 2001

\begin{tabular}{lcclcc}
\hline Sample site 11 & 1996 & 2001 & Sample site 12 & 1996 & 2001 \\
\hline Trees & 31.8 & 29.6 & Trees & 19.5 & 18.3 \\
Shrubs & 0 & 0 & Shrubs & 0 & 0.9 \\
Dwarf shrubs & 0.1 & 2.7 & Dwarf shrubs & 0.1 & 2.9 \\
Grasses & 5.0 & 6.9 & Grasses & 6.2 & 10.4 \\
Forbs & 0.1 & 3.0 & Forbs & 0.1 & 0.3 \\
\hline Total & 37.0 & 42.2 & Total & 25.9 & 32.8
\end{tabular}

Terminalia sericea occurred at high densities. With the exception of one site (Site 1, Community 1) the grass cover increased throughout the farm, as did forb cover. The changes in plant cover and structure can probably be explained by the change in landuse (from cattle farming to game farming) as well as the high precipitation occurring during the period under review (Edwards pers. comm.-Edwards, Charles, P.O. Box 26739 Monument Park, Pretoria, 0105). The increase in grass and forb cover can probably be attributed to the removal of cattle at high stocking rates and the introduction of game

Table 6

Change in species numbers per growth form in Community 3 on the farm Weltevreden between 1996 and 2001

\begin{tabular}{|c|c|c|c|c|c|}
\hline \multicolumn{3}{|c|}{ Sample site 11} & \multicolumn{3}{|c|}{ Sample site 12} \\
\hline $\begin{array}{l}\text { Number of woody } \\
\text { plant species }\end{array}$ & 1996 & 2001 & $\begin{array}{l}\text { Number of woody } \\
\text { plant species }\end{array}$ & 1996 & 2001 \\
\hline Trees & 4 & 4 & Trees & 4 & 4 \\
\hline Shrubs & 0 & 0 & Shrubs & 0 & 1 \\
\hline Dwarf shrubs & 5 & 8 & Dwarf shrubs & 3 & 11 \\
\hline $\begin{array}{l}\text { Total number of woody } \\
\text { species \& species turnover }\end{array}$ & $\begin{array}{c}9 \\
1 \mathrm{~T}, \\
1 \mathrm{DS} \text { missing }\end{array}$ & $\begin{array}{c}12 \\
4 \mathrm{DS} \\
\text { new }\end{array}$ & $\begin{array}{l}\text { Total number of woody } \\
\text { species \& species turnover }\end{array}$ & $\begin{array}{c}7 \\
0 \text { DS } \\
\text { missing }\end{array}$ & $\begin{array}{c}16 \\
1 \mathrm{~T}, 7 \mathrm{DS} \\
\text { new }\end{array}$ \\
\hline Number of grass species & 1996 & 2001 & Number of grass species & 1996 & 2001 \\
\hline Annuals & 1 & 3 & Annuals & 1 & 2 \\
\hline Perennials & 2 & 10 & Perennials & 5 & 7 \\
\hline $\begin{array}{l}\text { Total number of grass } \\
\text { species \& species turnover }\end{array}$ & $\begin{array}{c}3 \\
1 \text { missing }\end{array}$ & $\begin{array}{c}13 \\
11 \text { new }\end{array}$ & $\begin{array}{l}\text { Total number of grass } \\
\text { species \& species turnover }\end{array}$ & $\begin{array}{c}6 \\
0 \text { missing }\end{array}$ & $\begin{array}{c}9 \\
3 \text { new }\end{array}$ \\
\hline $\begin{array}{l}\text { Total number of forb species } \\
\& \text { species turnover }\end{array}$ & $\begin{array}{c}1996 \\
1 \\
0 \text { missing }\end{array}$ & $\begin{array}{c}2001 \\
9 \\
8 \text { new }\end{array}$ & $\begin{array}{l}\text { Total number of forb } \\
\text { species \& species turnover }\end{array}$ & $\begin{array}{c}1996 \\
4 \\
1 \text { missing }\end{array}$ & $\begin{array}{c}2001 \\
7 \\
4 \text { new }\end{array}$ \\
\hline $\begin{array}{l}\text { Total species for all } \\
\text { growth forms }\end{array}$ & 13 & 34 & $\begin{array}{l}\text { Total species for all } \\
\text { growth forms }\end{array}$ & 26 & 45 \\
\hline
\end{tabular}


including grazers, browsers and mixed feeders, at relatively low stocking rates.

All six re-surveyed sites reflected an increase in plant species richness and this increase was most substantial in Community 3 where the total number of plant species increased from 17 in 1996 to 34 in 2001 (Site 11) and from 26 in 1996 to 45 in 2001 (Site 12). Species in the grass, forb and to a lesser extent dwarf shrub growth form categories were responsible for this large increase. The species in the trees and shrubs growth form categories remained constant or increased slightly. This trend, i.e. grasses, forbs and dwarf shrubs being responsible for most of the nett gain in species richness, was reflected in the other two communities as well but not as marked as in Community 3.

The proportion of forb species to other plant species in a given area is often an indication of the condition of the veld since most of these plants are opportunistic by nature. In other words, they occupy the space left by more permanent and often desirable plant species, which have been reduced in cover and frequency usually due to some environmental impact, either climatic or herbivory. The mean proportion of forbs to other plants (in terms of species richness) on Weltevreden in 2001 was relatively high at $27 \%$ and in combination with the low mean grass cover of $13 \%$ (for the same year), taken in isolation this would be cause for concern. However, the mean grass cover for 1996 was only $10 \%$ and when consideration is given to the low mean cover for forbs at $1.3 \%$ (for 2001) and that the proportion of grass plants to the other species is high at $34 \%$, then it becomes evident that the veld is recovering from historical overgrazing.

\section{Conclusions}

This study has shown that traditional areabased vegetation survey techniques (such as a Braun Blanquet approach) can be used for the detection of change in species composition if great care is taken with sample site relocation and species identification. These problems can be alleviated by the use of permanent demarcation of sample sites and the collection of voucher plant specimens.

The canopy cover estimations using the plant number scale of Westfall and Panagos (1988) are an improvement compared to other frequently used cover-abundance scales, such as the Braun-Blanquet or the Domin Krajina scales (Mueller-Dombois \& Ellenberg 1974). This is largely due to the use of 33 cover classes in the plant number scale as well as a physical count of species in variable-sized transects based on average crown size and average gaps between individuals of the same species. The Braun-Blanquet cover scale makes use of only six classes and the Domin Krajina cover scale makes use of ten classes and observations are visually estimated usually from a sedentary position in the middle of the quadrat. Nevertheless, the quantification of canopy cover using the plant number scale remains an estimation. This is due to problems associated with the choice of direction of the variable-sized transect in which the count of species is conducted and the definition of what constitutes an individual plant. Future monitoring efforts using area-based techniques should make use of absolute abundances (such as a density count) rather than cover estimations.

Although this application shows some changes in the vegetation of the area, the technique's analysis excludes estimation of data dispersion, hence precision cannot be calculated. Much as point methods are susceptible to shortcomings in terms of adequate sample size (Reilly \& Panagos 2001) area-based methods run the risk of pseudoreplication (Hulbert 1984) and autocorrelation (Fortin et al. 1989) and survey designs need to be scrutinised in this regard if they are to achieve their potential in terms of monitoring change over time.

\section{Acknowledgements}

Professor Gerhard Malan of the Tshwane University of Technology, for reviewing the manuscript prior to submission. 


\section{References}

Acocks, J.P.H. 1988. Veld types of South Africa. Memoirs of the botanical Survey of South Africa 57: 1-146.

Agromet Database. 1996. Agricultural Research Council, Institute for Soil, Climate and Water, Pretoria.

Coates Palgrave, K. 1988. Trees of southern Africa. Cape Town: Struik.

DYKSTERHUIS, E.J. 1949. Condition and management of rangeland based on quantitative ecology. Journal of Range Management 2: 104-114.

ECKHARDT, H.C., N. VAN ROOYen \& G.J. BREDENKAMP. 1993. Use of Braun-Blanquet data for the assessment of veld condition and grazing capacity in grassland. African Journal of Range and Forage Science 10(1): 41-46.

EDWARDS, D. 1983. A broad scale structural classification of vegetation for practical purposes. Bothalia 14:705-712.

Everson, T.M., G.P.Y. Clarke \& C.S. Everson. 1990. Precision in monitoring plant species composition in montane grasslands. Vegetatio 88: 135-141.

FERRAR, A.A. 1983. Guidelines for the management of large mammals in African conservation areas. Pretoria: Council for Scientific and Industrial Research, National Scientific Programmes Unit. (South African National Scientific Programmes report; no. 69.)

Foran, B.D., N.M. TAINTON \& P. DE V. Booysen. 1978. The development of a method for assessing veld condition in three grassveld types in Natal. Proceedings of the Grassland Society of southern Africa 13:27-33.

Fortin, M, P. Drapeau \& P. LegendRe. 1989. Spatial autocorrelation and sampling design in plant ecology. Vegetatio 83:209-222.

Germishuizen, G. \& N.L. Meyer (eds.). 2003. The plants of southern Africa: an annotated checklist. Strelitzia 14.

Hulbert, S.H. 1984. Pseudoreplication and the design of ecological field experiments. Ecological Monographs 54(2): 187-211.

Land Type Survey Staff. 1988. Land Types of the maps 2426 Thabazimbi and 2428 Nylstroom. Memoirs of the Agricultural Natural Resources of South Africa No. 10.

Levy, E.B. \& E.A. MADDEN. 1933. The point method of pasture analysis. New Zealand Journal of Agriculture 6:267-279.

MACVICAR, C.N., J.M. DE VILLIERS, R.F. LOXTON, E. Verster, J.J.N. Lambrechts, F.R. MERryWEATHER, J. LE ROUX, T.H. VAN ROOYEN \& H.J. vON M. HARMSE. 1977. Soil classification: A binomial system for South Africa. Pretoria: Soil and Irrigation Research Institute, Department of Agricultural Technical Services.
Mentis, M.T. 1981. Evaluation of the wheel-point and step-point methods of veld condition assessment. Proceedings of the Grassland Society of southern Africa 16:89-94.

Mentis, M.T. 1984. Monitoring in South African grasslands. Pretoria: Council for Scientific and Industrial Research, National Scientific Programmes Unit. (South African National Scientific Programmes report; no. 91.)

Mentis, M.T., R.H.F. Collinson \& M.G. Wright. 1980. The precision of assessing components of the condition of moist tall grassveld. Proceedings of the Grassland Society of Southern Africa 15: 43 - 46.

Mueller-Dombois, D. \& H. Ellenberg (eds.). 1974. Aims and methods of vegetation ecology. New York: Wiley.

O'ConNoR, T.G. \& P.W. Roux. 1995. Vegetation changes (1949-71) in a semi-arid, grassy dwarf shrubland in the Karoo, South Africa: influence of rainfall variability and grazing by sheep. Journal of Applied Ecology 32 (3): 612-626.

Panagos, M.D. 1995. A comparative classification of the Sourish Mixed Bushveld on the farm Roodeplaat (293 JR) using quadrat and point methods. MSc thesis, University of Natal, Pietermaritzburg.

Panagos, M.D. \& P.J.K. Zacharias. 1995. Research Note: A time and motion study for two vegetation survey techniques. African Journal of Range and Forage Science 12(1): 81-84.

Panagos, M.D., K.M. van Staden, R.H. Westfall \& P.J.K. ZaCharias. 1998. The plant communities of the Roodeplaat Experimental Farm, Gauteng, South Africa and the importance of classification verification. South African Journal of Botany 64(1): 44-61.

Reilly, B.K. \& M.D. Panagos. 2002. Statistical power of commonly used point methods in grassland monitoring. African Journal of Range and Forage Science 19:117-122.

Rutherford, M.C. \& R.H. WestFall. 1986. Biomes of southern Africa An objective categorization. Memoirs of the botanical Survey of South Africa 54:1 98

SHORT, A.D., T.G. O'CONNOR \& C.R. HurT. 2003. Medium-term changes in grass composition and diversity of Highland Sourveld in the southern Drakensberg in response to fire and grazing management. African Journal of Range and Forage Science 20(1):1-10.

SMIT, G.N. 1989. Quantitative description of woody plant communities: Part I. An approach. Journal of the Grassland Society of southern Africa 6(4): 186-194.

StaSoft InC. 1995. STATISTICA for Windows. Tulsa, OK: StaSoft, Inc. (http://www.stasoft.com)

TAINTON, N.M., P.J. EDWARDS \& M.T. MENTIS. 1980. A revised method for assessing veld condition. 
Proceedings of the Grassland Society of southern Africa 15: 37-42.

Trollope, W.S.W. 1990. Development of a technique for assessing veld condition in the Kruger National Park using key grass species. Journal of the Grassland Society of southern Africa 7(1): 46-51.

VAN OUdTSHOORN, F.P. 1992. Guide to grasses of South Africa. Pretoria: Briza.

VAN WYK, A.E. \& S.J. Malan. 1988. Veldgids tot die veldblome van die Witwatersrand en Pretoria gebied, insluitend Magaliesberg en Suikerbosrand. Cape Town: Struik.

WestFall, R.H. \& M.D. Panagos. 1988. The plant number scale: an improved method of cover estimation using variable sized belt transects. Bothalia 18:289 291 .
WestFall, R.H., N. van ROOYEN \& G.K. THeron. 1983. Veld condition assessments in Sour Bushveld. Proceedings of the Grassland Society of southern Africa 18:73-76.

WestFall, R.H., G.K. THERON \& N. van RoOYen. 1997. Objective classification and analysis of vegetation data. Plant Ecology 132:137-154.

Westfall, R.H., J.M. van Staden, M.D. Panagos, P.J.J. Breytenbach \& A. GreefF. 1996. Scale related vegetation sampling. Pretoria: Agricultural Research Council, Range \& Forage Institute (Roodeplaat).

Zambatis, N. 2002. Revised procedures for veld condition assessment in the Kruger National Park. Unpublished report, Scientific Services, Kruger National Park, Skukuza. 